\title{
The cost of organised transnational economic crime: a case study from the health sector
}

by Dayanath Jayasuriya

This article focuses on transnational organised crime as it relates to the health sector in the context of the misuse of precursor chemicals, without which most drugs of abuse under international control cannot be manufactured.

$\mathrm{I}$ t is generally taken for granted that economic crime exacts a heavy price but not many studies have been done in the past to identify vulnerable sectors or the magnitude of losses, except those of a direct and obvious nature. One area where organised crime has made a major impact is the health sector. The threat of chemical agents being used by terrorists looms large, and there have been reports of such agents being deployed in Japan and possibly Vietnam and elsewhere. Terrorists tend to use whatever they can access in order to maximize damage and attract publicity, and in this scenario the use of chemical agents becomes a potent and convenient tool of destruction.

John Bentivoglio, Special Counsel for Health Care Fraud and Chief Privacy Officer, US Department of Justice, reminded his audience at the Symposium on Healthcare Internet and E-Commerce, Washington DC, on March 27, 2000 that over a decade ago, Janet Reno, the then Attorney-General of the United States, described health care fraud as the second priority for the US Department of Justice (the first priority was violent crime). Janet Reno herself, speaking to the American Hospital Association Annual Membership Meeting, Washington DC, on February 2, 1998, stated that between 1992-98 health care fraud prosecutions and investigations in the United States had increased by 400\% . In 1997 more than a billion dollars had been recovered by way of criminal fines, civil settlements and administrative penalties.

This figure, however, pales into insignificance in the context of findings (also referred to by Janet Reno) that a staggering sum of US $\$ 20$ billion had been overpaid by the Medicare Programme to hospitals, doctors and other healthcare providers. In one instance, a psychiatrist and his corporation had billed the government for over $\$ 5.2$ million, claiming that the psychiatrist himself had provided the services when in fact unlicensed therapists had been deployed for the purpose. In the same year, more than 2,700 businesses and individuals had been blacklisted from future participation in federal health care programmes.

Investment in health care is massive; what has been detected in the United States, for instance, was described by Janet Reno as not mere fraud but "outright fraud". The situation is worse in other countries that do not have effective audit and law enforcement agencies focusing on the health sector. Transparency International's 2006 Global Corruption Report highlights fraud in the healthcare sector in many countries around the world. The Report provides case studies of fraud in the provision of pharmaceuticals and in the disbursement of funds for national AIDS control programmes.

\section{CORRUPTION OR FRAUD IN THE DOMESTIC SETTING}

Corruption or fraud in the domestic health care setting occurs in many ways, such as the following:

- manipulation of the tender and procurement system;

- submission of false claims for reimbursement;

- improper selection of health care providers and facilities;

- use of counterfeit drugs and charging for more expensive branded products;

- inappropriate payments or benefits to health care providers by drug companies and hospitals; 
- theft of property such as drugs and medical devices;

- use of inappropriate or unnecessary interventions or tests;

- malpractices including conflict of interest and unauthorized work practices;

- improper access to and sharing of confidential patient data; and,

- negligence and abuse of authority.

In some cases, these are well planned and orchestrated; in others, these occur in an ad hoc manner and after a "test run" become widespread and part of the "culture of corruption".

The list of corrupt practices in the health sector is expanding all the time, and the revelations contained in Transparency International's Report of 2006 are just the tip of the iceberg. What happens within AIDS programmes in some countries and some institutions is simply shocking. In the wake of the Tsunami disaster large sums of money became available for rehabilitation work, but reports from Sri Lanka and Indonesia, for instance, exemplify how funds have been siphoned off to enrich a few to the detriment of the unfortunate many. A few examples of the corrupt practices identified so far include: malpractice in the award of tenders for reconstruction projects; houses which pose a health hazard; poorly constructed roads and bridges which might collapse at any time; allocation of houses even to those who were not affected by the Tsunami; and, public utility services that provide dirty water. In Sri Lanka, an abandoned baby was claimed by several women, and custody was finally awarded by the courts to the biological mother as determined by DNA tests.

\section{IMPACT OF ORGANISED TRANSNATIONAL ECONOMIC CRIME ON HEALTH SERVICES}

Organised transnational economic crime and its impact on the health services is an area that does not appear to have received much attention. This article will, therefore, focus on transnational organised crime as it relates to the health sector in the context of the misuse of precursor chemicals.

The regulation of drug trafficking is not new; in Sri Lanka, for instance, a 17th century law banned the marketing of opium. Corruption within the public sector has received much attention in the new United Nations Convention Against Corruption. Interestingly, the Sri Lankan law enacted in 1675 provided for the banishment from the island of public servants who were convicted of drug offences. Banishment of nationals is no longer considered as a traditional form of penal sanction; however, a law on pharmacies and pharmacists drafted recently in the Maldive Islands provided for banishment for repeat offences. The penalty for a first time offence was not only a fine but also house arrest.
Domestic drug-related laws as well as the international drug control treaties until the 1980s focused on plants from which narcotic drugs can be derived as well as on the finished products such as heroin or cocaine or LSD. Cannabis and raw opium are the substances of abuse that can be used in their natural form. Others must go through a chemical process. Given the less than satisfactory result in preventive and law enforcement efforts in controlling the production, distribution and use of drugs of abuse, the United Nations and Member States took a significant step forward in drafting a new international Convention against Illicit Traffic in Narcotic Drugs and Psychotropic Substances. The Convention was adopted in 1988.

Article 12 of the Convention provides for the regulation of chemicals (known as "precursors") without which most drugs of abuse under international control cannot be manufactured. A regulatory approach was adopted because the legitimate uses for these chemicals make their prohibition impossible (see further, Jayasuriya,DC, "South Asia: Precursor Control- Current and Emerging Trends", Journal of Financial Crime, Vol 7 (3), 2000, 270-73.

One of the 24 chemicals regulated by the Convention is Acetic anhydride - a chemical used, for instance, in the manufacture of paracetamol, the over-the-counter pain killer. It is also used in car batteries, as a nail polish remover, and as a dye in the garment industry. Without acetic anhydride it is not possible to convert opium (morphine) into heroin. Acetic anhydride is manufactured in about 20 countries only by legitimate firms for licit purposes.

The rationale for regulation is simple; restrict access to legitimate uses and make it impossible for the drug mafia to use it to manufacture heroin. However, all that the illicit drug industry in countries such as Afghanistan and Myanmar requires to manufacture heroin for a year is a mere $.004 \%$ of total acetic anhydride production; hence the drug mafia attempts to divert supplies from manufacturing plants, warehouses, retail and wholesale outlets and even during transit.

The cost of such diversions is staggering. In India, for instance, even transport vehicles have been hijacked and the truck driver and other passengers brutally murdered. In Australia, a pharmacist was shot dead in an attempt to steal a small quantity of another chemical. The official price of a litre of acetic anhydride in India, for instance, is approximately $\$ 2$.Outside the factory, smugglers will offer bribes amounting to as much as five times the chemical's value; near the Indo-Pakistan border it would fetch 10-20 times more.

The investment is worthwhile for one reason. The illicit drug industry's annual turnover is estimated at US\$400 billion, or approximately $8 \%$ of the total global international trade (see UNDCP, World Drug Report, Oxford University Press, Oxford, p 124). A farmer in Pakistan is paid only $\$ 80$ for a kilogram of opium. After conversion 
into morphine and then to heroin, the value of one kilogram of heroin in the streets of New York, for instance, is approximately $\$ 290,000$. This massive profit would not be possible without the illicit drug industry having access to a small quantity of this vital chemical.

When countries exercise greater vigilance to prevent diversions through strict import/export controls, monitoring, and sharing of information, new supply sources and routes emerge (see further United Nations, Report of the INCB for 2005: Precursors and Chemicals Frequently Used in the Illicit Manufacture of Narcotic Drugs and Psychotropic Substances, New York, 2006). When it became difficult to smuggle acetic anhydride from India to Afghanistan through Pakistan, acetic anhydride manufactured in China was smuggled to Afghanistan through the Central Asian Republics - a circuitous route which exploited porous borders and untrained customs and border control officials.

\section{CONTROL OF PRECURSORS}

The control or precursors has an interesting political dimension to it. Indo-Pakistan cooperation in drug control matters commenced in the mid-1990s, when due to pressure exerted by the US government both countries were forced to enter into an agreement. Bilateral talks took place at periodic intervals, but at enforcement level the ground reality was quite different. For instance, it was not possible for an officer in either country to speak to his or her counterpart over the telephone and arrange a controlled delivery or share information with regard to an imminent diversion unless special permission was sought a process bound to take a month of Sundays. Arranging a test match between the two countries in the midst of political tension perhaps took much less time.

One of the worst cases of diplomatic interference occurred when authorities in Thailand intercepted a shipment of ephedrine from India to North Korea. This chemical is a vital ingredient in the manufacture of cough syrups and broncho-dilators, but is misused by the drug mafia to manufacture amphetamines. South Korean authorities alleged that North Korea had no legitimate requirement for such a large quantity of this chemical, which was to be used to illicitly manufacture amphetamines and flood the South Korean and Japanese markets. The abuse of amphetamines is a major problem it is estimated by the United Nations Office for Drug Control that out of the 200 million who abuse drugs worldwide, approximately 35 million use amphetaminetype stimulants.

The North Korean authorities asserted that due to a severe winter millions were sick and badly needed cough medicines. The country had no foreign exchange to import large quantities of the finished product, and hence domestic production was the only viable option. It was only after several months of acrimonious exchanges and interventions by the United Nations that the shipment was finally released; by the time it reached North Korea and cough medicines were eventually manufactured and marketed, it may have been too late for many.

The diversion of precursor chemicals is a well orchestrated criminal activity involving groups in several countries across many continents. Diversion routings are becoming more complex., forgeries of the signatures of authorized importers are becoming more sophisticated, and professional chemists have been kidnapped to work for the drug mafia to experiment new methods of manufacturing drugs using chemicals not under international control. Since reputable chemicals manufacturers have risk minimization and due diligence systems in place, attempts are being made to set up clandestine manufacturing plants.

The international law enforcement community is better equipped today than in 1988 when the Convention was adopted to intercept diversions. However, new reports from the United Nations Office for Drugs Control that opium production in Afghanistan has dramatically increased in 2006 are a cause for concern, particularly because of the possible increase in the availability of heroin worldwide if the required precursor chemicals can be accessed.

\section{LESSONS TO BE DRAWN FROM OPERATIONS OF ORGANISED CRIME NETWORKS}

This case study illustrates several interesting dimensions to the operations of organised criminal networks. The direct and indirect costs of these operations is beyond what can be quantified. There are several lessons that can be drawn from this case study, namely:

- Even where an international treaty has created obligations, effective implementation depends on domestic factors such as political will; skills and ability of those who are entrusted with responsibilities; and cooperation of all countries.

- Unfounded concerns can cause immense damage and loss if certain countries act upon such concerns without being satisfied as to their basis or the justification for intervention.

- Law enforcement must focus on interceptions throughout the chain of events since it is much easier to detect and prevent during the early stages of an operation;

- A delicate balance needs to be struck between "legitimate needs" on the one hand and "misuse or abuse" on the other, and regulations must not impose an unduly heavy or disproportionate burden.

- Since criminals tend to be one step ahead of law enforcement efforts, preventive measures must be adapted based on changing trends. 
Good health is often taken for granted, and the value of health care services and products is generally realized only in times of medical need, pain and suffering. The evolution of health care services worldwide has brought out the best in some individuals, who with dedication and determination have done their utmost to improve care, and the worst in a few others who have exploited opportunities for fraud and corruption.
We salute those who serve humanity, and must stand united to condemn the few who have disgraced and continue to disgrace humanity. (c)

Dr Dayanath Jayasuriya

Visiting Professor of Law, University of the Free State, South Africa;

formerly Chief Technical Adviser, United Nations International Drug

Control Programme

\section{IALS News}

\section{Report assesses performance and future direction of the Public Defender Service}

The Public Defender Service has achieved its objective of providing a good quality service that is equal to, and in many respects better than, the general standard provided by private practice in comparable areas, according to an independent research report.

The research was carried out by a team headed by Professor Avrom Sherr, Director of the IALS, and Professor Lee Bridges of the University of Warwick. It was based on an analysis of the six PDS offices during the Service's first three years of operation from 2001-04, and the report was published in January.

On the issue of cost, the report concluded that over the research period the case that the PDS can provide general criminal defence services at a comparable cost to contract providers remains unproven. Figures showed that the PDS was much more expensive, with average costs in the first three years of operation running at between $40-90$ per cent higher than those of comparable private practice. However, various factors connected with the start-up process combined to ensure that all the public defender offices (PDOs) operated below capacity in terms of chargeable hours per fee earner throughout the period of the research.

The report found that in relation to case processing and legal advice there was evidence that PDO advisers were more likely to attend in person on clients held in police stations than their counterparts in private practice. There was also a clear pattern in several areas of PDO lawyers advising clients to use their right of silence more often, and this appears to have benefited PDO clients in police stations by making them less likely to be charged or summoned for a criminal offence than clients of private practice. No such significant differences were recorded in the processing of cases in magistrates' courts or the Crown Court, or in terms of sentences received.
When assessing quality and independence the report felt that perhaps the greatest strength of the PDS in comparison to private practice lay in its ability to present good information, well communicated to clients in well structured files. In the report's opinion, the best basis for evaluating quality is provided by the peer review process, where case work is assessed by independent and experienced criminal defence professionals. However, the report also drew on the views of criminal justice professionals surveyed, whose overwhelming view was that there was little perceptible difference between the quality of service provided by the public defender offices and private practitioners in their areas. The exception to this conclusion was the views of solicitors in private practice.

During the early days of the service, the report considered that the PDS's devolved management structure contributed to a lack of consistency in management and quality of services in offices during the early days. This structure was replaced in 2004, with PDS office heads becoming responsible for both management and professional matters to the head of the service, an experienced criminal defence solicitor. Staff morale however was good, and contributed to the standards of service achieved; the client-focused, not-for-profit quality service principles of the PDS were valued by its employees, many of whom had previous experience of private practice.

A loud note of discord was struck by the Legal Aid Practitioners Group. Director Richard Miller called for an end to what he termed "the scandal of continuing with this expensive project", and criticized the PDS for its quality of service in relation to the private sector considering the amount of public money given to it and the lower number of chargeable hours worked.

In summary, the report found that one of the main lessons to be learned from its evaluation and the PDS pilot project was the need for a clear understanding of the policy objectives behind the PDS by the government, the Legal Services Commission (LSC), and the staff of the PDS. The government had tended to see the PDS as a mixed system for the delivery of criminal defence services which both 